\title{
SOSIALISASI PENCEGAHAN EKSPLOITASI SEKSUAL ANAK SELAMA MASA PANDEMI COVID-19 DI SURABAYA
}

\section{SOCIALIZATION OF PREVENTING CHILD SEXUAL EXPLOITATION DURING THE COVID-19 PANDEMIC IN SURABAYA}

\author{
Chriestine Lucia Mamuaya, Sari Dewi Poerwanti", Mohammad Suud \\ Program Studi Kesejahteraan Sosial, Fakultas Ilmu Sosial dan Ilmu Politik \\ Universitas Wijaya Kusuma Surabaya \\ *Email: saridewipoerwanti@gmail.com \\ (Diterima 12-09-2021; Disetujui 24-09-2021)
}

\begin{abstract}
ABSTRAK
Pengabdian masyarakat dengan tajuk pencegahan eksploitasi seksual anak selama masa pandemi ini dilatarbelakangi oleh peningkatan angka kasus eksploitasi seksual pada anak secara signifikan yang dilakukan secara daring selama masa pandemi COVID-19. Selama pemerintah menerapkan kebijakan pembelajaran jarak jauh, sebagian besar anak waktunya dihabiskan di rumah tentu dengan gawai yang terhubung dengan internet. Tanpa disadari semakin lama anak akan merasa jenuh dan kesepian, di sisi lain sering kali orang tua atau anggota keluarga tidak melakukan pengawasan secara optimal penggunaan gawai pada anak. Tingginya risiko anak berselancar internet dan bertemu orang asing melalui media sosial berpengaruh pula pada tingginya risiko anak menjadi korban predator anak di dunia maya. Kegiatan pengabdian masyarakat ini terdiri atas sosialisasi dan pendampingan konseling secara daring dengan sasaran orang tua murid dan guru sekolah dasar di SDN Sidotopo 1 Surabaya. Adapun capaian dari kegiatan pengabdian masyarakat adalah kelompok sasaran mengalami peningkatan pengetahuan dan kewaspadaan terhadap fenomena eksploitasi seksual pada anak secara daring terutama di masa pandemi Covid-19. Hal ini dibuktikan dengan hasil evaluasi yang menunjukan peningkatan secara signifikan dan kepuasan akan layanan pendampingan konseling sebesar $90 \%$. Ke depan, diharap kegiatan pengabdian masyarakat ini akan mencapai cangkupan sasaran kelompok yang lebih luas.
\end{abstract}

Kata Kunci : eksploitasi seksual, perlindungan anak, orang tua, internet

\begin{abstract}
Community Service with the title of preventing sexual exploitation of children during this pandemic is motivated by the significant increase in the number of cases of sexual exploitation of children carried out online during the COVID-19 pandemic. As long as the government implements a distance learning policy, most of the children's time is spent at home, of course, with devices that are connected to the internet. Without realizing it the longer the child will feel bored and lonely, on the other hand often parents or family members do not optimally supervise the use of gadgets in children. The high risk of children surfing the internet and meeting strangers through social media also has an effect on the high risk of children becoming victims of child predators in cyberspace. This community service activity consists of socialization and online counseling assistance with the target of parents and elementary school teachers at SDN Sidotopo 1 Surabaya. The achievement of community service activities is that the target group has increased knowledge and awareness of the phenomenon of sexual exploitation of children online, especially during the Covid-19 pandemic. This is evidenced by the evaluation results which show a significant increase and satisfaction with counseling assistance services by $90 \%$. In the future, it is hoped that this community service activity will reach a wider range of target groups.
\end{abstract}

Keywords: sexual exploitation, child protection, parents, internet

\section{PENDAHULUAN}

Selama pemerintah menerapkan kebijakan Pembelajaran Jarak Jauh (PJJ), sebagian besar anak waktunya dihabiskan di rumah tentu dengan gawai yang terhubung dengan internet. Intensitas penggunaan internet selama masa pandemi memposisikan anak dalam 
Sosialisasi Pencegahan Eksploitasi Seksual Anak Selama Masa Pandemi Covid-19 di Surabaya

Chriestine Lucia Mamuaya, Sari Dewi Poerwanti, Mohammad Suud

kondisi rentan terhadap kejahatan daring (cybercrime), salah satunya kasus yang sering ditemui adalah eksploitasi seksual online. Menurut data Forbes yang dilansir dalam harian Media Indonesia (2020) laporan National Center for Missing and Exploited Children (NCMEC) dibandingkan bulan April 2020, pada bulan maret 2020 terjadi pelonjakan angka kasus Eksploitasi Seksual Anak (ESA) online sebanyak dua juta laporan.

Dalam konteks negara Indonesia secara umum Kementerian Pemberdayaan Perempuan dan Perlindungan Anak (Kemen PPPA) merilis data selama masa pandemi COVID-19 ini dari Sistem Informasi Online Perlindungan Perempuan dan Anak yang dilansir oleh Tirto.id (2020), diketahui selama awal tahun 2020 hingga pertengahan tahun 2020 terdapat 300 laporan kasus kekerasan terhadap anak. Secara khusus bentuk kekerasan anak yaitu eksplotasi seksual anak secara daring sendiri menurut hasil riset kuantitatif tahap awal selama masa pandemi COVID-19 yang dilakukan oleh ECPAT (2020) diketahui bahwa dari total jumlah responden 1.203 anak yang tersebar di 13 provinsi di Indonesia, terdapat 287 anak mengaku memiliki pengalaman buruk saat menjelajahi internet. Adapun pengalaman buruk yang diterima anak-anak tersebut antara lain menerima pesan yang mengandung unsur tidak senonoh, selain pesan teks anak juga menerima pesan gambar ataupun video yang menampilkan unsur ketelanjangan dan sejenisnya yang membuat tidak nyaman dan dapat dikategorikan pada konten pornografi.

Pada penelitian tahap lanjutan masih yang dilakukan oleh ECPAT (2020) diketahui dari 10 terdapat 3 anak yang mengalami kekerasan secara daring/online antara lain adalah: 1) pesan teks tidak senonoh baik inteprestasi dirinya ataupun temannya, 2) menerima konten berbentuk gambar/video porno baik secara langsung ataupun melalui tautan, dan 3) menerima konten berbentuk gambar/video yang membuat tidak nyaman baik inteprestasi dirinya ataupun temannya. Sebagian besar responden yang menerima perlakuan buruk saat berinternet tersebut adalah responden perempuan. Jika anak menjadi korban eksplotasi seksual secara daring tentu akan berdampak pada masa depannya; bukan hanya pada tumbuh kembang secara fisik, tetapi juga kejiwaannya terutama jika anak korban eksploitasi seksual ini tidak segera ditangani dan didampingi dengan baik ke depan terdapat kemungkinan anak tersebut mengalami trauma. Menurut Notosoerdirdjo dkk (2007), terdapat potensi gangguan mental yang dapat terjadi pada anak antara lain adalah gangguan kecemasan berpisah (separation anxiety disorder), gangguan tingkah laku (conduct disorder), retardasi mental (mental retardation), gangguan pemusatan perhatian dan hiperaktif (attention deficit and hyperactive disorder), gangguan beroposisi yang menyimpang (deviant oposisional disorder), dan gangguan kelekatan reaktif (reactive 
attachment disorder). Menurut penelitian yang dilakukan Komisi Perlindungan Anak Indonesia yang dilansir pada Harian Kompas (2020), terdapat kecenderungan sebesar 75 persen korban eksploitasi seksual anak memiliki kerentangan menjadi pelaku saat dewasa jika tidak memperoleh penanganan secara tuntas.

Hasil asesmen diketahui beberapa masalah di SDN I Sidotopo antara lain pertama anak khususnya yang berada pada jenjang pendidikan dasar kurang memahami batasan seksualitas diri dan tindakan apa saja yang membahayakannya saat berselanjar di internet. Kedua, sebagian besar orang tua belum paham dan sadar pentingnya pengawasan dan pendampingan penggunaan internet pada anak serta cara pencegahan terjadinya tindak eksploitasi sesksual anak secara daring. Ketiga rendahnya tingkat partisipasi sekolah dalam proses tranfer informasi terkait pendidikan seksual sejak dini karena peran sekolah umumnya terlalu berfokus pada pencapaian kurikulum pembelajaran dan nilai akademik murid. Keempat, baik pihak keluarga maupun sebagian guru mengalami gagap teknologi sehingga tidak mampu mengimbangi anak dalam penggunaan gawai yang terhubung. Akhirnya akan berdampak pada rendahnya pengawasan dan pendampingan pada anak.

Berdasarkan analisis situasi dan identifikasi masalah yang telah dijabarkan di atas tersebut, maka diketahui penting untuk intervensi secara holistik kepada seluruh aktor yang terlibat dengan cara penguatan kapasitas baik kelompok anak ataupun orang tua mengenai pentingnya pengawasan dan penggunaan yang baik dalam literasi digital agar terhindar dari permasalahan kejahatan daring (cybercrime) terutama eksploitasi seksual pada anak. Berlandaskan dari itu, maka tim pengabdian kepada masyarakat merasa terpanggil untuk berkontribusi dalam upaya preventif kepada masyarakat terutama pada masa pandemi ini. Tim pengabdian kepada masyarakat bersinergi bersama masyarakat dalam hal ini orang tua murid, sekolah dan pemerintah setempat dalam melakukan pengabdian dengan tema "Pencegahan Eksploitasi Seksual Anak Selama Masa Pandemi Covid-19".

\section{BAHAN DAN METODE}

Kegiatan pengabdian kepada masyarakat memiliki target sasaran sejumlah 20 orangtua murid serta guru SDN Sidotopo I Surabaya. Kegiatan pengabdian masyarakat dilaksanakan secara daring menggunakan media Zoom meeting dan Whatsapp Group dengan dua tahapan, yaitu sosialisasi tahap satu berupa pelatihan online dilaksanakan pada tanggal 23 Desember 2020, Kemudian sosialisasi tahap dua berupa kegiatan edukasi menggunakan media infografik dan pembukaan layanan konseling bagi peserta. Adapun alasan kegiatan dilaksanakan secara daring adalah untuk meminimalisir penyebaran virus 
COVID-19 dengan pembatasan sosial terlebih Kota Surabaya masih menjadi salah satu kantong penyumbang penderita COVID-19 di Indonesia. Beberapa metode yang digunakan dalam kegiatan pengabdian kepada masyarakat adalah sebagai berikut:

1. Ceramah

Metode ceramah ini dipilih untuk menyampaikan konsep-konsep yang penting mengenai pentingnya menerapkan protokol kesehatan dalam kehidupan sehari-hari agar dimengerti dan dikuasai oleh peserta kegiatan. Adapun alasan penggunaan metode ini dengan pertimbangan bahwa metode ceramah yang dikombinasikan dengan bahan presentasi yang menarik seperti menampilkan data, ilustrasi, dan gambar-gambar dapat memberikan materi yang relatif banyak secara padat, cepat dan mudah.

2. Tanya Jawab

Metode ini penting bagi para peserta untuk saling memberi masukan tentang pencegahan eksploitasi seksual anak secara daring di masa pandemi Covid-19 dan segala permasalah yang ada. Dengan metode ini pula, peserta diharapkan dapat penggali sebanyak-banyaknya tentang kerangka penguatan.

\section{Simulasi}

Metode ini penting untuk dijadikan referensi bagi peserta agar mendapatkan gambaran dari berbagai merancang dan pemanfaatan media interaksi dalam pencegahan eksploitasi seksual anak secara daring di masa pandemi Covid-19 sehingga peserta bisa menyesuaikan dengan kebutuhan dan permasalahan di keluarganya.

\section{HASIL DAN PEMBAHASAN}

Pelaksanaan kegiatan pengabdian masyarakat yang dilakukan merupakan kegiatan sosialisasi dan pelatihan pencegahan eksploitasi seksual anak selama masa pandemi Covid19. Sebelum dilaksanakan terlebih dahulu tim pengabdian melakukan persiapan dengan membangun raport dan kerja sama antara tim dan pihak SDN 1 Sidotopo Surabaya. Kemudian tim bersama pihak sekolah mulai memetakan peserta sasaran kegiatan yang sesuai untuk tema eksploitasi seksual anak, kebutuhan kegiatan, penentuan tempat dan waktu pelaksanaan. 


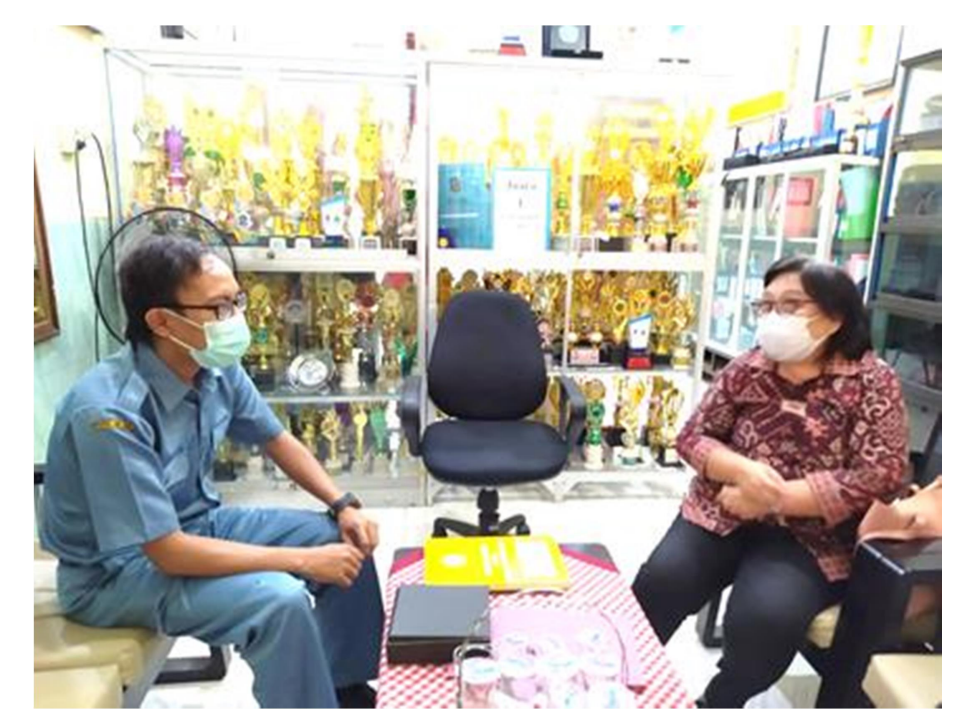

Gambar 1. Tahap persiapan tim pengabdian dan pihak sekolah Sumber: Dokumentasi Tim Pengabdian, 2020

Setelah pertemuan pertama, selanjutnya adalah pembukaan pendaftaran peserta serta pengisian formulir pre-test melalui google form oleh calon peserta untuk mengukur pemahaman dasar peserta terkait tema kekerasan seksual pada anak. Hasil dari pre-test diketahui bahwa sebagian besar peserta sasaran mengetahui pengertian kekerasan seksual sebatas pada tindakan langsung/fisik semata, padahal bentuk kekerasan seksual sangatlah banyak terutama di dunia maya baik disadari ataupun tidak oleh korban. Setelah peserta mendaftar dan mengisi form pre-test, peserta dikumpulkan dalam satu wadah komunikasi yaitu Whatsapp Group untuk mempermudah koordinasi acara dan proses konseling pada tahap lanjutan.

Tahap pelaksanaan, sosialisasi dilakukan secara daring melalui aplikasi Zoom. Adapun materi yang diberikan terdiri atas tiga konsentrasi mengenai kekerasan seksual anak yaitu:

1. Kajian Kebijakan : Dr. Drs. Mohammad Suud, MA

Pencegahan Eksploitasi Seksual Anak Selama Masa Pandemi Covid-19

2. Kajian Keluarga : Dra. Chriestine L. Mamuaya, M.IP

Peran Orang Tua dalam Pencegahan Eksploitasi Seksual Anak di Masa Pandemi

3. Kajian Teknologi : Sari Dewi Poerwanti, S.Sos., M.Kesos

Lindungi Anak Kita dari Eksploitasi Seksual Anak Online di Masa Pandemi Covid-19

Setelah penyampaian materi, peserta sasaran diberi kesempatan untuk mengajukan pertanyaan terkait materi kegiatan.

Pada tahap selanjutnya adalah tahap sosialisasi lanjutan tim memanfaatkan Whatsapp group yang telah dibentuk di awal kegiatan untuk mengadakan sosialisasi lanjutan tahap 
kedua yang dibungkus secara ringkas, ringan, menarik dan mudah dipahami berupa infografik dan media visual lainnya terkait tema pencegahan eksploitasi seksual anak selama masa pandemi Covid-19. Media visual tersebut akan dikirimkan secara rutin setiap hari selama 1 (satu) bulan.
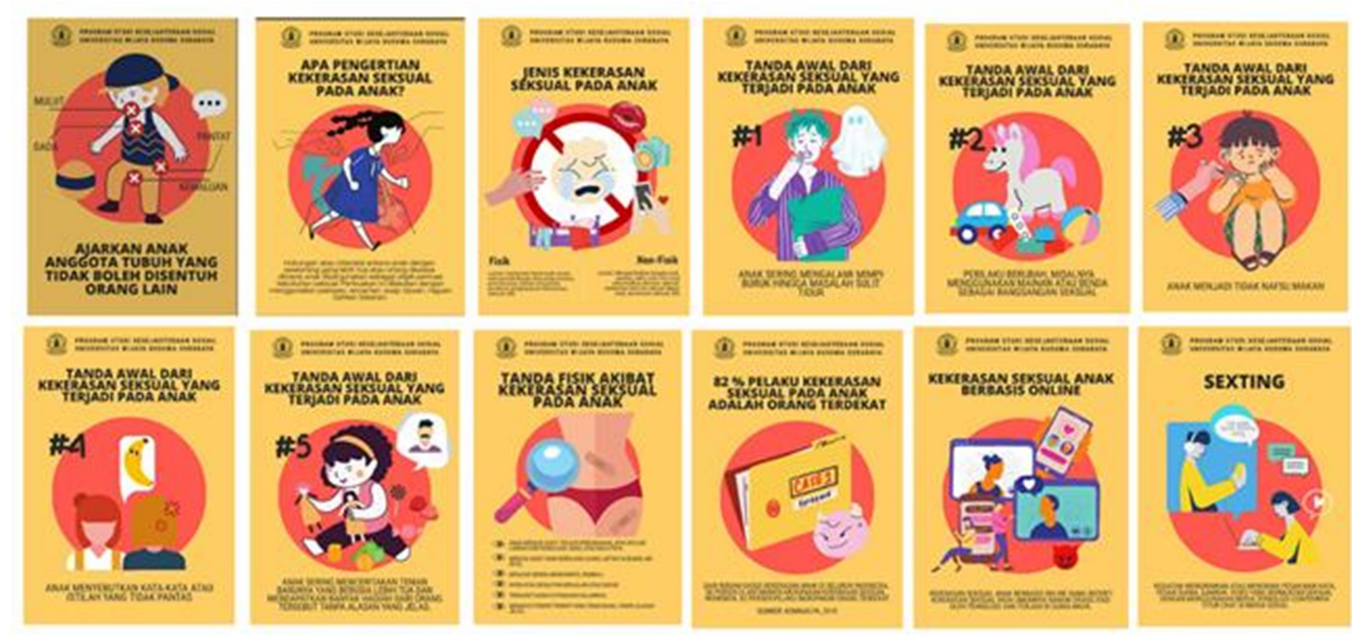

Gambar 2. Contoh materi infografik kekerasan seksual anak yang didistribusikan oleh tim Sumber: Dokumentasi Tim Pengabdian, 2021

Beriringan dengan pelaksanaan sosialisasi tim pengabdian juga melakukan layanan konseling terkait tema kekerasan seksual pada anak. Namun, mengingat kondisi dan situasi tidak kondusif diakibatkan oleh pandemi Covid-19 untuk membuka layanan konseling secara luring, maka tim pengabdi melaksanakan layanan konseling secara daring dengan memanfaatkan media Whatsapp group yang telah terbentuk sebelumnya pada tahap pertama. Untuk kasus yang sifatnya lebih sensitif tim juga menyediakan jaringan pribadi untuk menjaga kerahasiaan informasi. Pada tahap ini tidak semua peserta mengikuti konseling, hanya peserta yang memiliki masalah dan bersedia dengan sukarela melakukan konseling. Di akhir kegiatan dilaksanakan post-test melalui google form terkait penyerapan materi kegiatan.

Tabel 1. Distribusi responden berdasarkan pengetahuan yang diterima

\begin{tabular}{cccccc}
\hline \multirow{2}{*}{ No } & Kategori & \multicolumn{2}{c}{ Pre-Test } & \multicolumn{2}{c}{ Post-Test } \\
\cline { 3 - 6 } & & $\mathrm{N}$ & Persentase (\%) & $\mathrm{N}$ & Persentase (\%) \\
\hline 1. & Rendah & 9 & 45,00 & 1 & 5,00 \\
2. & Sedang & 7 & 35,00 & 11 & 55,00 \\
3. & Tinggi & 4 & 20,00 & 8 & 40,00 \\
\hline & Jumlah & 20 & 100,00 & 20 & 100,00 \\
\hline \multicolumn{4}{r}{}
\end{tabular}

Sumber: Analisis Data Primer (2021) 
Berdasarkan T 1. diketahui pada pre-test pengetahuan, terdapat 9 responden (45\%) yang rendah dan post test menjadi 1 responden (5\%) dengan pengetahuan rendah. Terdapat 7 respoden (35\%) dengan pengetahuan sedang pada pre test, naik menjadi 11 respoden (55\%) pada post test. Terdapat 4 responden (20\%) dengan pengetahuan tinggi pada pre test dan meningkat menjadi 8 responden (40\%) setelah post test. Sedangkan hasil kepuasan konseling sebesar $90 \%$ peserta konseling merasa puas atas pelayanan yang diterima saat proses konseling.

Peningkatan hasil pre test dan post test menjadikan hasil uji menunjukkan bahwa terdapat perubahan signifikan antara pre test dan post test. Perbedaan ini membuktikan bahwa peserta kegiatan telah menerima materi sosialisasi kekerasan seksual anak secara daring dengan baik dan puas terhadap pelayanan konselor saat kegiatan konseling oleh tim.

\section{KESIMPULAN DAN SARAN}

Pelaksanaan kegiatan pengabdian masyarakat tahap pertama adalah sosialisasi dan pelatihan pencegahan eksploitasi seksual anak selama masa pandemi Covid-19 dengan wali murid dan wali kelas sebagai kelompok sasaran kegiatan. Pada tahap ini kegiatan berjalan dengan sangat baik. Terdapat tiga konsentrasi kajian yang disampaikan pada peserta sasaran terkait tema, yaitu dari segi kebijakan, segi konseling dan segi penggunaan teknologi.

Seluruh target tercapai sesuai dengan rencana yang telah disusun sebelumnya antara lain ketercapaian jumlah target peserta yaitu berjumlah 20 orang. Kedua, ketercapaian tujuan pemberdayaan yakni melakukan sosialisasi dan pelatihan pencegahan eksploitasi seksual anak selama masa pandemi Covid-19 pada orang tua murid dan wali kelas. Ketiga, ketercapaian peningkatan keterampilan pencegahan dan monitoring media internet anak agar terhindar dari kasus eksploitasi seksual anak secara daring di masa pandemi Covid-19. Keempat, ketercapaian peningkatan pengetahuan dan kesadaran masyarakat mengenai eksploitasi seksual anak secara daring. Hal ini dapat diketahui melalui hasil pre-test dan post-test yang menunjukan peningkatan pemahaman. Kelima, ketercapaian kemampuan peserta menciptakan ide atau gagasan kreatif dalam menumbuhkan kerekatan anak dan orang tua melalui aktivitas yang berisi konten pendidikan seksual. Hal ini terlihat pada sesi tanya jawab dan sharing session. Terakhir adalah antusias peserta kegiatan yang terlihat dari keterlibatan peserta baik dalam menjawab pertanyaan, memberi pertanyaan, ataupun diskusi. Seluruh peserta mengikuti kegiatan dari awal hingga akhir. 
Sosialisasi Pencegahan Eksploitasi Seksual Anak Selama Masa Pandemi Covid-19 di Surabaya

Chriestine Lucia Mamuaya, Sari Dewi Poerwanti, Mohammad Suud

Berdasarkan kesimpulan di atas, maka tim dapat memberikan beberapa saran antara lain akan lebih baik jika kegiatan pelatihan dilakukan secara luring dengan mengaktifkan kembali LP3 di Fakultas Ilmu Sosial dan Ilmu Politik UWKS. Tentu dengan konsekuensi terdapat pemangkasan jumlah target sasaran dan peningkatan pengawasan prokes saat kegiatan berlangsung karena bertujuannya untuk meminimalisir penyebaran virus Covid19. Selain itu, dengan metode luring penyerapan atau tranformasi informasi akan lebih efektif dan efisien dilakukan.

\section{DAFTAR PUSTAKA}

Aliansi Down to Zero Indonesia. 2020. Press Release: Pentingnya Edukasi Orang Tua dan Teman Sebaya Tentang Bahaya Eksploitasi Seksual Anak di Masa Pandemi Covid19. https://ecpatindonesia.org/publikasi-media/press-release-pentingnya-edukasiorang-tua-dan-teman-sebaya-tentang-bahaya-eksploitasi-seksual-anak-di-masapandemi-covid-19/ (diakses pada 11 November 2020).

Harian Kompas. 2020. KPAI Ungkap Penyebab Anak-anak Mudah Jadi Korban Eksploitasi Seks. https://megapolitan.kompas.com/read/2020/01/30/08391761/kpaiungkap-penyebab-anak-anak-mudah-jadi-korban-eksploitasi-seks?page=all (diakses pada 24 Oktober 2020)

Kementerian Pemberdayaan Perempuan dan Perlindungan Anak. 2019. Buku Panduan Terminologi Perlindungan Anak dari Eksploitasi. Jakarta: Kementerian Pemberdayaan Perempuan dan Perlindungan Anak

Media Indonesia. 2020. Survei: 3 dari 10 Anak Alami Kekerasan Seksual di Masa Pandemi. $\quad$ https://mediaindonesia.com/read/detail/359887-survei-3-dari-10-anakalami-kekerasan-seksual-di-masa-pandemi (diakses pada 11 November 2020).

Notosoerdirdjo, Moeljono, Latipun. 2007. Kesehatan Mental, Konsep dan Penerapan, Malang: UMM Press.

R.A. Koesnan. 2005. Susunan Pidana dalam Negara Sosialis Indonesia. Bandung : Sumur Sulianta, Feri. 2010. Cyberporn: Bisnis atau Kriminal. Jakarta: Elex Media Komputindo Tirto.id 2020. Kemen PPPA Catat 3.000 Kasus Kekerasan Anak selama Pandemi COVID19. https://tirto.id/kemen-pppa-catat-3000-kasus-kekerasan-anak-selama-pandemicovid-19-fK3j (diakses pada 24 Oktober 2020)

Yudhanti, Ristina. 2014. Perempuan dalam Pusaran Hukum. Yogyakarta: Thafa Media 